유화 작품 색맞춤용 재료 특성 연구

- 복원용 물감과 아크릴과슈를 중심으로 -

\title{
A Study on the Retouching Materials for Oil Paintings - Using Restoration Colors and Acrylic Gouache -
}

\author{
최희진 ${ }^{1}$, 강대일2,* \\ ${ }^{1}$ 한국전통문화대학교 문화유산전문대학원 문화재수리기술학과, ${ }^{2}$ 한국전통문화대학교 문화재보존과학과 \\ Hee Jin Choi ${ }^{1}$, Dai III Kang ${ }^{2, *}$ \\ ${ }^{1}$ Department of Heritage Conservation and Restoration Graduate School of Cultural Heritage, Korea National University of \\ Cultural Heritage, Buyeo 33115, Korea \\ ${ }^{2}$ Department of Heritage Conservation Science, Korea National University of Cultural Heritage, Buyeo 33115, Korea
}

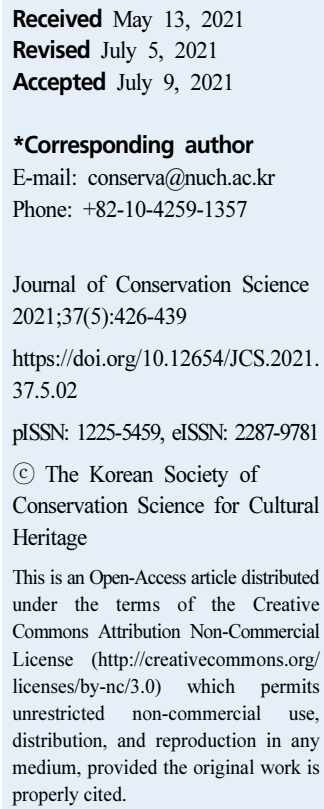

\begin{abstract}
초 록 유화 색맞춤에 사용되는 복원용 물감과 아크릴과슈에 대하여 물감별 특성을 파악하고 자외 선 및 흡습건조 열화실험을 통하여 복원재료로서의 내구성을 확인하였다. 4 개 제조사에서 제작된 총 20 종의 물감을 사용하였으며 분석 결과 동일한 색명의 물감일지라도 제조사별 성분 및 발색 특성 차이가 존재했다. 이는 제조 시 체질, 착색 안료로 사용된 안료의 차이에서 기인한 것으로 판단된다. 열화 후 대부분의 시료에서 $\triangle E^{*} 12.0$ 이상의 변색이 일어났으며, $\mathrm{C}$ 사의 Viridian에서는 광택 변화도 관찰되었다. Lemon Yellow에서는 변색과 균열이 모두 관찰되었다. 균열은 복원용 물감 인 $\mathrm{B}$ 사의 것에서 가장 많이 발생했다. 이는 제조 시 사용된 수지의 영향인 것으로 추측되나 향후 정확한 원인 규명을 위해 변수를 통제하여 추가적인 연구가 진행되어야 할 것이다. 연구를 통해 색맞춤용 재료의 색 및 제조사에 따른 물리적 특성 차이가 확인되었으므로, 유화 보존처리 자는 색맞춤 시 재료별 변색, 균열, 광택 변화와 같은 물리적 특성을 고려하여 복원재료의 선정 및 사용에 신중해야 할 것이다.
\end{abstract}

중심어 유화, 색맞춤, 복원용 물감, 아크릴과슈, 내구성

ABSTRACT In this study, we compare the properties and estimate the durability of five oil colors that are the most popularly used colors in the conservation of oil paintings. A set of these colors was obtained form four manufacturers each, and their properties were analyzed by conducting deterioration experiments. Subsequently, we observed the colors and performed X-ray fluorescence analysis. As a result of colour observation and XRF analysis, it was confirmed that there are the differences according to the pigment types, mixing rations and the manufacturers even for colors having the same product name. The deterioration test indicated differences in the appearance of the colors ; for instance, the color difference was above 12.0 in most of the samples, including restoration color and acrylic gouache. In the case of Lemon Yellow a lot of discoloration and cracking occurred, and difference in gloss was observed in Viridian of manufacturer C. Most cracks were observed in the restoration color obtained from manufacturer B and were assumed to be because of the resin used by the manufacturer. Nevertheless, additional research will have to be conducted by controlling variables in order to find out the cause. Through this study, we demonstrated that retouching materials for conservation of oil painting differed in their physical properties according to the color and manufacturer. Therefore a conservator should be mindful during the selection and use of materials for retouching oil paintings.

Key Words Oil painting, Retouching, Restoration colors, Acrylic gouache, Durability 


\section{1. 서 론}

유화작품의 보존처리는 '처리 전 상태조사 - 클리닝 - 약 화된 물감층의 강화 및 재접합 - 캔버스 및 그림틀 보강박락 부위 메움, 성형 - 색맞춤 보호 처리'순으로 진행된다. 이 중 ‘성형'은 작품의 균열 또는 결손부에 행하는 색맞춤을 뜻하며, 최종 바니시 처리 전 복원 작업의 마지막 단계로 물감층을 처리하는 단계이다. 이탈리아의 미술사학자인 체 사레 브란디(Cesare Brandi)는 "모든 그림은 미학적, 역사적 역할을 하며, 따라서 보존처리 시 이 두 역할을 모두 고려해 야 한다.”고 말한바 있으며, 물감층은 그림의 미학적 역할을 하는 주된 층이기에 이런 물감층을 처리하는 단계인 색맞춤 은 그림의 외형뿐만 아니라 작품의 가치를 좌우하는 유화작 품의 보존처리 시 가장 중요한 단계라고 할 수 있다.

색맞춤에 사용되는 재료는 다양하다. 과거에는 린시드 유(Linseed oil)나 매스틱(mastic) - 댐머(dammar)와 같은 천연수지를 안료와 섞어 사용하거나 수채물감 등을 사용 했으며 최근에는 합성수지를 미디엄으로 하는 복원용 물 감(Restoration color 또는 Conservation color)과 아크릴과 슈(Acrylic gouache)가 사용되고 있다. 이처럼 색맞춤에 사 용되는 재료들은 매우 다양하며 이들은 재료에 따른 내구 성, 취급 특성 등의 차이를 지닐 뿐 아니라 같은 종류의 재료라 하더라도 제조사에 따라 그 특성에 차이를 지닌다.

현재 시판되는 일반 유화물감과 같이 복원용 물감과 아크릴과슈 역시 제조사별 다른 조색법에 따른 성분 차이 를 지닐 것이다. 이러한 성분의 차이는 내구성에 영향을 미치게 되며, 이는 결국 변색 - 균열 등 화학적, 물리적 변 화를 발생시켜 유화 작품의 손상을 초래하게 된다. 또한 색맞춤에 사용되고 있는 재료의 열화 특성에 관한 정보는 유화작품 보존관리에서 매우 중요하다.

이에 본 연구에서는 국내에서 유화작품 보존처리 시 색맞춤에 주로 사용되고 있는 복원용 물감과 아크릴과슈 를 선정하여 성분 분석 및 인공 열화를 실시하고 이를 통 해 색맞춤에 사용되고 있는 재료의 제조사별 물리적 특성 을 비교해보고자 하였다.

현재까지 유화 색맞춤용 재료에 관한 연구는 전반적으 로 부족하며, 특히 비교적 최근에 개발된 복원용 물감의 경우 관련된 연구가 더욱 미비한 실정이다. 국내에서 유 화물감과 관련된 연구로는 일반 유화물감을 중심으로 안 료 및 매재 분석을 주로 하여 내광성(Lee, 2009), 열화 실 험(Kim, 2008), 유화물감의 재질적 특성 비교 연구(Kim, 2017)가 진행된바 있다. 그러나 실제 유화작품 색맞춤에 사용되고 있는 복원용 물감과 아크릴과슈의 성분분석, 내 구성 연구 등 이들 재료에 관한 연구는 진행된바 없다.

\section{2. 이론적 배경}

색맞춤은 작품의 손상된 물감층 부분을 다시 칠해 원 래 상태로 회복시키는 과정을 말한다. 본격적으로 색맞춤 의 중요성을 인식하고 다양한 논의가 시작된 것은 20세기 에 들어오면서부터라고 할 수 있으며, 오늘날에는 유화를 비롯한 회화작품의 보존처리에 있어 색맞춤 기법, 과정에 대한 다양하고 구체적인 논의가 진행되고 있다. 그럼에도 불구하고 색맞춤 기법과 과정, 재료에 대한 의견들은 하 나로 통합되지 못하고 있으며 색맞춤 재료의 선정 기준에 대해서도 명확히 정해진바 없다.

색맞춤은 작품의 보존성에는 직접적으로 영향을 미치 는 단계는 아니다. 오히려 잘못 실행할 경우 작품의 외관 과 작품이 지닌 가치, 역사를 손상시킬 수 있으며 색맞춤 후 관람자로 하여금 그림의 미적, 역사적 가치를 인식하는 데도 영향을 미치게 된다. 일부 학자들은 이를 '미학적 사 치(esthetic luxury)'라고 평가하기도 한다(Nicolaus, 1999). 이런 의견을 종합해 보았을 때 색맞춤은 신중하게 진행되 어야 하는 단계라는 것을 알 수 있다.

따라서 색맞춤 시에는 향후 재처리 시 제거가 필요할 경우 작품을 손상시키지 않는 가역성이 있는 재료를 써야 하며 안정성, 작업 시 용이성과 같은 기준을 고려해 가장 적합한 재료를 선택해 사용해야 한다. 특히 가역성과 안 정성을 중요시하는 현대 보존이론 원칙을 고려해야 한다.

오늘날 색맞춤에 사용되는 재료는 다양하며 앞서 말한 기준 외에도 결손부위의 형태, 결손부에 처리한 메움제 등에 따라 재료를 결정한다. 이들은 크게 전색제의 차이 에 따라 구분된다. 아직까지 가장 보편적으로 사용되고 있는 재료는 아라비아 검(Gum arabic)을 기반으로 하는 수채물감이며 최근에는 아크릴과슈와 다양한 수지를 기 반으로 한 복원용 물감도 함께 많이 사용하고 있다.

수채물감은 수용성으로, 가역성이 좋고 황변이 심하지 않기에 과거부터 주로 사용되어 왔다. 최근에는 물에 쉽 게 용해되고 내광성이 좋다고 알려진 Poly(2-ethyl-2oxazoline) 중합체인 Aquazol을 기반으로 제작한 새로운 형태의 수채물감이 개발되어 색맞춤에 사용되고 있다 (Wolbers, 1994). 그러나 수채물감은 한 번의 덧칠로는 유 화 특유의 색감과 기법을 표현하기 어려울 뿐 아니라 물 감이 건조됨에 따라 색이 달라질 수 있어 처리자의 많은 경험이 필요하다는 단점을 지닌다.

아크릴과슈는 과슈(gouache)와 아크릴물감(acrylic color) 의 특성을 모두 지닌 물감을 말한다. 이는 과슈처럼 불투 명 수채화이지만, 건조 후 내수성을 지니는 아크릴 수지 를 미디엄으로 한 물감이므로 아크릴물감으로 분류된다. 
물감층을 두껍게 올려 표현할 수 있으며 일반 유화물감과 용매가 다르기에 유화 작품의 색맞춤에 사용되고 있는 재료이다. 아크릴과슈는 두터운 질감 표현이 가능해 수채 물감보다는 다양한 기법을 표현할 수 있지만 유화 특유의 광택과 색감을 표현하기는 어렵다는 한계를 지닌다(Geiger, 2005).

복원용 물감은 유향수지와 같은 천연수지나 ureaaldehyde와 같은 합성수지를 미디엄으로 하는 물감이다. 기존에 사용되던 색맞춤 재료에서 발생한 균열, 변색과 같은 단점을 극복하기 위해 개발된 재료로 Restoration color, Conservation color라는 이름으로 시판되고 있다. 실 제 작품의 색맞춤에는 1990년대 말 René de la Rie의 제안 에 따라 영국 내셔널 갤러리(National gallery)에서 사용된 것을 시작으로, 현재 국내외에서 유화 작품 색맞춤에 많 이 사용되고 있는 재료이다. 복원용 물감은 일반 유화물 감과 용매가 다르기에 재처리 시 기존 물감층에 영향을 주지 않고 제거 가능하며 다양한 기법으로 제작된 유화 작품의 색맞춤에 사용하기 적합한 물감으로 평가받고 있 다. 또한 기존에 사용되던 색맞춤 재료들보다 안정적이라 고 알려져 있다.

\section{3. 재료 및 방법}

\section{1. 연구재료}

실험에 사용한 물감은 3 원색인 적색, 황색, 청색을 포 함하여 녹색과 갈색 총 5 가지 색상으로 구분하였다. 기준 에 따라 선정된 물감은 적색의 Carmine 4종, 황색의 Lemon Yellow 4종, 녹색의 Viridian 4종, 청색의 Ultramarine blue 4종, 갈색의 Burnt Sienna 4종이다. 국내외에서 유화 작품 색맞춤에 사용하고 있다고 확인된 제조사의 물감을 선정하였으며, 2 개 제조사의 복원용 물감(A社, B社) 및 2 개 제조사의 아크릴과슈(C社, $\mathrm{D}$ 社)로 총 4 개 제조사에서 제작된 20종의 물감을 이용하였다(Table 1).

\subsection{1. 시편제작}

시편은 $4 \times 4 \mathrm{~cm}$ 크기로 재단한 캔버스 천 위에 물감을 올려 5 배수로 제작하였다. 바탕천으로는 유화 작품 제작 에 가장 많이 사용되는 아사천을 사용하였으며, 채색 시 에는 충분한 은폐력이 발휘될 수 있도록 $2 \mathrm{~mm}$ 두께로 물 감을 채색하였다. 물감이 건조되는 기간은 색/제조사마다

Table 1. The list of Colors samples for experiment

\begin{tabular}{|c|c|c|c|}
\hline No. & Color & Color name (Color Index name) & Manufacturer \\
\hline 01 & \multirow{4}{*}{ Red } & Alizarin permanent carmine (PR177) & A \\
\hline 02 & & Permanent carmine (PR83) & $\mathrm{B}$ \\
\hline 03 & & Carmine (PR170) & $\mathrm{C}$ \\
\hline 04 & & Carmine (PR146, PR170) & $\mathrm{D}$ \\
\hline 05 & \multirow{4}{*}{ Yellow } & Cadmium yellow lemon (PY35) & A \\
\hline 06 & & Cadmium yellow lemon (PY35) & B \\
\hline 07 & & Lemon yellow (PY3) & $\mathrm{C}$ \\
\hline 08 & & Lemon yellow (PY3, PW6) & $\mathrm{D}$ \\
\hline 09 & \multirow{4}{*}{ Blue } & Ultramarine blue (PB29) & A \\
\hline 10 & & Ultramarine (PB29) & B \\
\hline 11 & & Ultramarine blue (PB29) & $\mathrm{C}$ \\
\hline 12 & & Ultramarine blue light (PB29) & $\mathrm{D}$ \\
\hline 13 & \multirow{4}{*}{ Green } & Viridian (PG18) & A \\
\hline 14 & & Viridian (PG18) & $\mathrm{B}$ \\
\hline 15 & & Viridian (PG7, PB15:3) & $\mathrm{C}$ \\
\hline 16 & & Viridian (PG7, PY3) & $\mathrm{D}$ \\
\hline 17 & \multirow{4}{*}{ Brown } & Burnt sienna $(\mathrm{PBr} 7)$ & A \\
\hline 18 & & Burnt sienna (PBr7) & B \\
\hline 19 & & Burnt sienna (PR101) & $\mathrm{C}$ \\
\hline 20 & & Burnt sienna (PBr7) & $\mathrm{D}$ \\
\hline
\end{tabular}


조금씩 다르고, 평균적으로 2 3주의 기간이 필요하기에 충분한 건조를 위해 28 일간 직사광선이 닿지 않는 곳에서 자연 건조 $\left(20 \pm 2^{\circ} \mathrm{C}, \mathrm{RH} 50 \%\right)$ 시켰다.

\subsection{2. 인공열화}

제조사별 물감의 내구성 확인을 위해 인공 열화를 실 시하였다. 열화는 자외선 열화 및 흡습·건조의 두 조건 으로 진행하였다.

자외선 열화 시험은 UV 기기(UV TEST II W/SPRAY, Atlas, USA)를 사용하였으며, 자외선 파장은 UV-A(310 $400 \mathrm{~nm}$ ), 자외선 조사량은 $0.89 \mathrm{~W} / \mathrm{m}^{3} / \mathrm{nm}$ 의 조건에서 14 일(336시간)간 시험을 진행하였다. 흡습 - 건조를 통한 인 공 열화는 항온항습기(TEMI 300, Daihan-sci, KOR)를 사 용해 14일(336시간)간 진행하였다. 열화 조건은 선행 연 구(Chelazzi, 2014)를 참고하되 기기의 작동 조건에 맞게 수정하였다. 열화 조건은 Table 2와 같다.

\section{2. 연구방법}

열화 전 시료를 대상으로 육안관찰과 색도 측정을 통 해 제조사별 발색 특성을 비교하였으며 형광X선분석 (XRF, X-Ray Fluorescence)을 실시하여 물감 내 무기 성분 차이를 분석하였다. 제조사별 물감의 내구성은 열화 전후 시료의 물리적 특성변화를 표면확대관찰(현미경), 색도 및 광택도 측정을 통해 비교하였다.

\subsection{1. 제조사별 물감 특성 분석}

발색특성은 시료를 열화시키기 전 육안관찰과 색도 측정을 통해 실시하였다. 명도 또는 색도의 차이가 뚜 렷하게 확인되는지 육안관찰로 구분하였으며, 객관적 인 비교를 위해 제조사별 물감의 색도를 휴대용 색채색 차계(CR-400, Konica Minolta, JPN)를 이용해 측정한 후 명도 $\left(\mathrm{L}^{*}\right)$ 와 색도 $\left(\mathrm{a}^{*}, \mathrm{~b}^{*}\right)$ 수치를 비교하였다. 측정 시에 는 시료 표면 5 곳을 3 회씩 측정한 후 평균값을 사용하

Table 2. Condition of Temperature and Humidity test

\begin{tabular}{cccc}
\hline & \multicolumn{3}{c}{ Condition } \\
\cline { 2 - 4 } No. & Time & $\begin{array}{c}\text { Temperature } \\
\left({ }^{\circ} \mathrm{C}\right)\end{array}$ & $\begin{array}{c}\text { Relative } \\
\text { humidity(\%) }\end{array}$ \\
\hline 1 & $42 \mathrm{~h}$ & $20 \pm 3{ }^{\circ} \mathrm{C}$ & $80 \%$ \\
2 & $42 \mathrm{~h}$ & $50 \pm 3{ }^{\circ} \mathrm{C}$ & $80 \%$ \\
3 & $42 \mathrm{~h}$ & $50 \pm 3{ }^{\circ} \mathrm{C}$ & $30 \%$ \\
4 & $42 \mathrm{~h}$ & $20 \pm 3{ }^{\circ} \mathrm{C}$ & $30 \%$ \\
5 & same as 1 to 4. & \\
\hline
\end{tabular}

였다.

물감 제조사에 따른 무기 성분 차이를 확인하기 위해 형광X선분석(XRF)을 실시하였다. Portable XRF(Vanta C-series, Olympus, JPN)를 이용하였으며 Geochem 모드에 서 전압 $40 \mathrm{kV}$ 에서 30 초, $15 \mathrm{kV}$ 에서 30 초 총 60 초로 시료 당 3 회씩 반복 측정하여 성분을 분석하였다.

\subsection{2. 내구성 평가}

열화 후 발생하는 균열과 같은 물감층 표면의 변화 를 관찰하기 위해 육안관찰과 Digital 현미경(DG-3, Scalar, JPN)을 사용해 100 배율로 시료 표면을 관찰하 였다.

광택도의 경우 열화 전후 표면 변화를 확인하기 위해 분광측색계(Spectro-guide, BYK, DEU)를 이용해 시료 표 면 5곳을 3 회씩 측정한 후 평균값을 사용하였으며, 열화 전후 값의 차이를 $\triangle \mathrm{G}$ 로 표시하였다.

$$
\triangle G=G_{2}-G_{1} \text { [ } G_{1} \text { : 열화 전 / } G_{2} \text { : 열화 후 ] }
$$

열화 전후 시료의 변색 정도를 비교하고자 휴대용 색 채색차계(CR-400, Konica Minolta, JPN)로 색도를 측정하 였다. 측정 방법은 발색특성 비교와 동일하게 진행하였 다. 측정값은 KS A 0063 규정에 의거해 $\mathrm{L}^{*} \cdot \mathrm{a}^{*} \cdot \mathrm{b}^{*}$ 로 표 시하였으며, 열화에 따른 변색 정도는 다음 식을 이용해 색차를 계산하였다. 색차값의 평가는 미국 국가 표준국 (NBS: National Bureau of Standard Unit)에 의한 등급을 적 용하여 실시하였다(Table 3).

$$
\begin{gathered}
\triangle E=\sqrt{\left(L_{1}-L_{2}\right)^{2}+\left(a_{1-} a_{2}\right)^{2}+\left(b_{1}-b_{2}\right)^{2}} \\
L_{1}, a_{1}, b_{1}: \text { 열화 전 } L^{*} a^{*} b \text { 값 } / \\
L_{2}, a_{2}, b_{2}: \text { 열화 후 } L^{*} a^{*} b \text { 값 }
\end{gathered}
$$

Table 3. Critical marks of color difference according to the NBS

\begin{tabular}{cc}
\hline$\Delta E^{*} a b$ & Critical marks of color difference \\
\hline $0.0-0.5$ & Trace \\
$0.5-1.5$ & Slight \\
$1.5-3.0$ & Noticeable \\
$3.0-6.0$ & Appreciable \\
$6.0-12.0$ & Much \\
$12.0-$ & Very much \\
\hline
\end{tabular}




\section{4. 결과 및 고찰}

\section{1. 제조사별 물감 특성 비교}

발색특성 비교 및 형광X선분석을 이용한 성분분석을 통해 복원용 물감과 아크릴과슈는 동일한 색명의 물감일 지라도 제조사별로 발색특성 및 구성성분에 차이가 있음 을 확인하였다.

먼저 발색특성 비교를 위하여 각 시료별 색상측정치 (Table 4)를 명도 $\left(\mathrm{L}^{*}\right)$ 와 색도 $\left(\mathrm{a}^{*}, \mathrm{~b}^{*}\right)$ 로 구분하여 제조사 간 상대적 비교를 수행하였다(Figure 1,2). 명도의 경우 적색의 Carmine은 32.39 42.65, 황색의 Lemon yellow는 $85.54 \sim 88.53$, 녹색의 Viridian은 $25.40 \sim 48.05$, 청색의 Ultramarine blue는 25.86 36.21, 갈색의 Burnt sienna는 $34.75 \sim 50.23$ 의 수치 분포를 보였다. 제조사 간 명도 편차 에서 가장 큰 차이를 보인 색상은 Viridian으로 육안관찰 에서 가장 뚜렷한 색상 차이를 보인 $\mathrm{C}$ 사의 물감이 $\mathrm{L}^{*}$ 25.40 으로 가장 명도가 낮았다. 색도 역시 제조사별 차이 를 확인할 수 있었는데, Carmine의 경우 B사의 물감이 다 른 제조사의 것에 비해 육안상 어둡게 보였는데 색도 측 정결과 $\mathrm{a}^{*} 43.52$ 로 다른 물감에 비해 적색도가 낮은 편이 었다. 육안관찰 시 제조사별 색 구분이 어려웠던 Lemon yellow는 A사의 물감이 다른 제조사의 것에 비해 $\mathrm{a}^{*}$ $-12.26, b^{*}$ 85.91로 다소 적색도와 황색도가 높은 것으로 나타났다. 육안관찰에서 제조사별 가장 뚜렷한 색차를 보 였던 녹색인 Viridian의 경우 명도와 마찬가지로 C사의 물 감이 색도 측정 수치상 차이를 보였는데 $\mathrm{a}^{*}-1.74$ 로 적색
도가 높은 편이었다. Ultramarine blue는 다른 색상에 비해 제조사 간의 색도 차이가 크지 않은 편이었으며, Burnt sienna의 경우 육안 관찰 시 다소 어두워 보였던 $\mathrm{B}$ 사의 물감이 a* $17.07, b^{*} 16.55$ 로 다소 적색도와 황색도가 낮은 편이었다.

다음으로 형광X선분석 결과 제조사에 따른 무기성분 차이를 확인할 수 있었다.

적색물감(Carmine) 분석 결과 $\mathrm{Ca}$ 이 모든 제조사에서 검출되었는데 이는 칼슘화합물이 체질안료로 사용된 데 서 기인한 것으로 보인다(Gettens, 1996). $\mathrm{Fe}$ 는 착색안료로 사용된 것으로 보이며, 그 외 적색 물감 착색에 영향을 주는 성분은 확인되지 않았다. 4 개의 제조사 모두 유기 색소를 사용한 것으로 추정된다.

황색물감(Lemon yellow)에서는 모든 제조사에서 $\mathrm{Ca}$ 가 검출되었으며 체질안료에서 기인한 것으로 보인다. 색명 에 Cadmium이 포함되어 있었던 $\mathrm{A}$ 사와 $\mathrm{B}$ 사의 물감에서는 Cadmium yellow의 주성분으로 알려진 $\mathrm{Cd}$ 과 $\mathrm{S}, \mathrm{Zn}$ 이 검출 되었다. 두 제조사의 경우 물감 제조 시 황화카드뮴 $(\mathrm{CdS})$ 과 황화아연 $(\mathrm{ZnS})$ 를 섞어 제작한 것으로 추정된다. $\mathrm{C}$ 사의 경우 $\mathrm{Ti}$ 와 $\mathrm{Fe}$ 가 높게 검출되었으며 $\mathrm{D}$ 사의 물감에서는 $\mathrm{Ca}$ 와 Ti가 높게 검출되었다. 모든 제조사에서 Lemon yellow 의 주성분으로 알려진 $\mathrm{Ba}$ 나 $\mathrm{Cr}(\mathrm{Kogou}, 2021)$ 은 검출되지 않았으며 유기 색소를 사용한 것으로 보인다. 따라서 4 개 제조사 모두 색명에 표기된 Lemon yellow는 재료 또는 화 학적 특성과 관련 없이 색에 따른 표기인 것으로 판단된다.

녹색물감(Viridian)의 경우 모든 제조사의 물감에서 $\mathrm{Ca}$ 가 검출되었으며 이는 다른 색과 마찬가지로 체질안료에

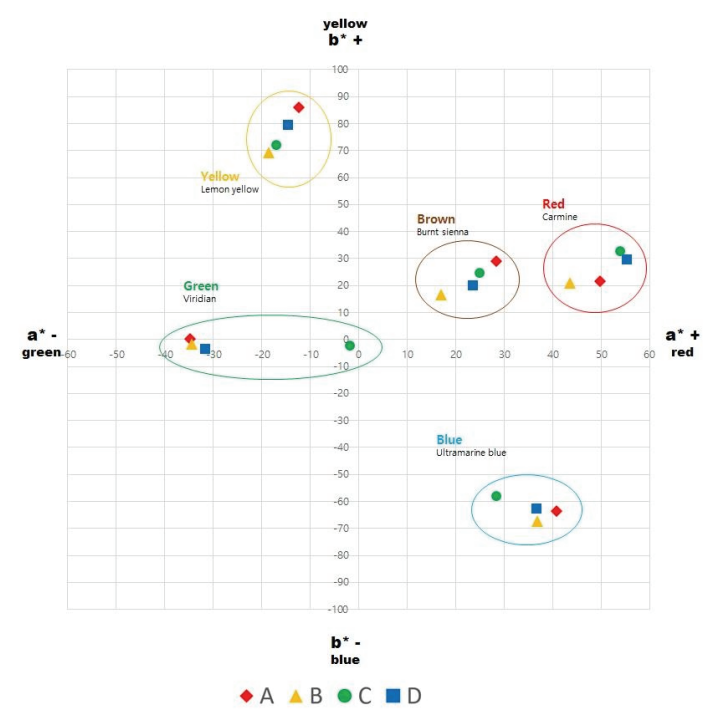

Figure 2. Chromaticity of experimental samples.

Figure 1. Lightness of experimental samples. 
서 기인한 것으로 보인다. A사와 B사는 Viridian의 주성분 으로 알려진 $\mathrm{Cr}$ 을 중심으로 하는 강한 피크를 보였으며, 별다른 성분은 검출되지 않았다. $\mathrm{D}$ 사의 경우 $\mathrm{Ca}$ 가 높게 검출되었다. C사와 $\mathrm{D}$ 사는 Viridian의 주성분으로 알려진 $\mathrm{Cr}$ 은 검출되지 않았으며 $\mathrm{Cl}$ 와 $\mathrm{Cu}$ 성분이 다소 높게 측정 되었다. 이 두 회사는 Viridian의 대용품(Seo, 2004)으로 개 발된 Phthalocyanine green을 사용한 것으로 추정되며, 단 순히 색에 따라 색명을 붙인 것으로 판단된다.
청색물감(Ultramarine blue) 분석 결과 체질안료에서 기 인한 것으로 보이는 칼슘이 검출되었다. 4 개 제조사 모두 Ultramarine blue의 주성분으로 알려진 $\mathrm{S}$ 과 $\mathrm{Si}, \mathrm{Al}$ 이 검출 되었으며, $\mathrm{Fe}$ 도 함께 검출되었다.

갈색(Burnt sienna)에서는 모든 제조사의 물감에서 $\mathrm{Fe}$ 가 높게 측정되었으며 $\mathrm{Ca}$ 가 함께 검출되었다. 색명에서 알 수 있듯 산화철을 기반으로 하는 안료로 제조되었으며 $\mathrm{Fe}$ 는 착색안료에서, $\mathrm{Ca}$ 는 체질안료에서 기인한 것으로 보인다.

Table 4. The colour differences in visual observation and chromaticity of colors

\begin{tabular}{|c|c|c|c|c|c|}
\hline \multirow{2}{*}{ Color } & \multirow{2}{*}{ Manufacturer } & \multicolumn{3}{|c|}{ VIS } & Pigment \\
\hline & & \multirow[t]{2}{*}{ Sample image } & \multicolumn{2}{|c|}{ Color } & Detected elements by XRF \\
\hline \multirow{12}{*}{ Red } & \multirow{3}{*}{ A } & & $\mathrm{L}^{*}$ & 36.52 & \multirow{3}{*}{$\begin{array}{l}\text { main : } \mathrm{Al}, \mathrm{Ca}, \mathrm{Fe} \\
\text { trace : } \mathrm{Cr}, \mathrm{Si}\end{array}$} \\
\hline & & & $a^{*}$ & 49.89 & \\
\hline & & & $b^{*}$ & 21.54 & \\
\hline & \multirow{4}{*}{ B } & & $\mathrm{L}^{*}$ & 32.39 & \multirow{4}{*}{$\begin{array}{l}\text { main : } \mathrm{Ca}, \mathrm{Fe} \\
\text { trace : } \mathrm{Ti}, \mathrm{Si}\end{array}$} \\
\hline & & & $\mathrm{a}^{*}$ & 43.52 & \\
\hline & & & $b^{*}$ & 20.85 & \\
\hline & & & $\mathrm{L}^{*}$ & 38.48 & \\
\hline & \multirow{2}{*}{$\mathrm{C}$} & & $a^{*}$ & 54.02 & \multirow{2}{*}{$\begin{array}{l}\text { main : } \mathrm{Ti}, \mathrm{Fe} \\
\text { trace : } \mathrm{Ca}, \mathrm{Si}\end{array}$} \\
\hline & & & $b^{*}$ & 32.83 & \\
\hline & \multirow{3}{*}{$\mathrm{D}$} & & $\mathrm{L}^{*}$ & 42.65 & \multirow{3}{*}{$\begin{array}{l}\text { main : } \mathrm{Ca} \\
\text { trace : } \mathrm{Fe}\end{array}$} \\
\hline & & & $a^{*}$ & 55.32 & \\
\hline & & & $b^{*}$ & 29.80 & \\
\hline \multirow{9}{*}{ Yellow } & \multirow{3}{*}{ A } & & $\mathrm{L}^{*}$ & 86.68 & \multirow{3}{*}{$\begin{array}{l}\text { main : } \mathrm{Cd}, \mathrm{Zn}, \mathrm{S} \\
\text { trace : } \mathrm{Ca}\end{array}$} \\
\hline & & & $a^{*}$ & -12.26 & \\
\hline & & & $b^{*}$ & 85.91 & \\
\hline & \multirow{3}{*}{ B } & & $\mathrm{L}^{*}$ & 88.53 & \multirow{3}{*}{$\begin{array}{l}\text { main : } \mathrm{Cd}, \mathrm{Zn}, \mathrm{S} \\
\text { trace : } \mathrm{Ca}\end{array}$} \\
\hline & & & $a^{*}$ & -18.54 & \\
\hline & & & $b^{*}$ & 69.30 & \\
\hline & \multirow{3}{*}{$\mathrm{C}$} & & $\mathrm{L}^{*}$ & 85.54 & \multirow{3}{*}{$\begin{array}{l}\text { main : } \mathrm{Ti}, \mathrm{Fe} \\
\text { trace : } \mathrm{Ca}\end{array}$} \\
\hline & & & $a^{*}$ & -17.04 & \\
\hline & & & $b^{*}$ & 72.00 & \\
\hline
\end{tabular}




\begin{tabular}{|c|c|c|c|c|}
\hline & \multirow{3}{*}{ D } & $\mathrm{L}^{*}$ & 88.20 & \multirow{3}{*}{$\begin{array}{l}\text { main }: \mathrm{Ca}, \mathrm{Ti} \\
\text { trace }: \mathrm{Fe}\end{array}$} \\
\hline & & $a^{*}$ & -14.65 & \\
\hline & & $b^{*}$ & 79.39 & \\
\hline \multirow{12}{*}{ Green } & \multirow{3}{*}{ A } & $\mathrm{L}^{*}$ & 44.6 & \multirow{3}{*}{$\begin{array}{l}\text { main }: \mathrm{Cr} \\
\text { trace }: \mathrm{Ca}\end{array}$} \\
\hline & & $\mathrm{a}^{*}$ & -34.85 & \\
\hline & & $b^{*}$ & 0.29 & \\
\hline & \multirow{3}{*}{ B } & $\mathrm{L}^{*}$ & 48.05 & \multirow{3}{*}{$\begin{array}{l}\text { main : } \mathrm{Cr} \\
\text { trace : } \mathrm{Ca}\end{array}$} \\
\hline & & $a^{*}$ & -34.50 & \\
\hline & & $b^{*}$ & -1.69 & \\
\hline & \multirow{3}{*}{$\mathrm{C}$} & $\mathrm{L}^{*}$ & 25.40 & \multirow{3}{*}{$\begin{array}{l}\text { main : } \mathrm{Cl}, \mathrm{Cu}, \mathrm{Ti}, \mathrm{Fe} \\
\text { trace : } \mathrm{Ca}\end{array}$} \\
\hline & & $a^{*}$ & -1.74 & \\
\hline & & $b^{*}$ & -2.21 & \\
\hline & \multirow{3}{*}{ D } & $\mathrm{L}^{*}$ & 38.84 & \multirow{3}{*}{$\begin{array}{l}\text { main : } \mathrm{Ca}, \mathrm{Cl} \\
\text { trace : } \mathrm{Cu}, \mathrm{Ti}\end{array}$} \\
\hline & & $\mathrm{a}^{*}$ & -31.67 & \\
\hline & & $b^{*}$ & -3.61 & \\
\hline \multirow{12}{*}{ Blue } & \multirow{3}{*}{ A } & $\mathrm{L}^{*}$ & 25.86 & \multirow{3}{*}{$\begin{array}{l}\operatorname{main}: \mathrm{S}, \mathrm{Fe}, \mathrm{Ca} \\
\text { trace : } \mathrm{Ti}, \mathrm{Si}, \mathrm{Al}\end{array}$} \\
\hline & & $a^{*}$ & 40.87 & \\
\hline & & $b^{*}$ & -63.49 & \\
\hline & \multirow{3}{*}{ B } & $\mathrm{L}^{*}$ & 33.20 & \multirow{3}{*}{$\begin{array}{l}\operatorname{main}: \mathrm{S}, \mathrm{Fe}, \mathrm{Ca} \\
\text { trace : } \mathrm{Si}, \mathrm{Al}\end{array}$} \\
\hline & & $a^{*}$ & 36.93 & \\
\hline & & $b^{*}$ & -67.30 & \\
\hline & \multirow{3}{*}{$\mathrm{C}$} & $\mathrm{L}^{*}$ & 36.21 & \multirow{3}{*}{$\begin{array}{l}\operatorname{main}: \mathrm{Ti}, \mathrm{S}, \mathrm{Ca} \\
\text { trace : } \mathrm{Fe}, \mathrm{Si}, \mathrm{Al}\end{array}$} \\
\hline & & $\mathrm{a}^{*}$ & 28.47 & \\
\hline & & $b^{*}$ & -58.01 & \\
\hline & \multirow{3}{*}{ D } & $\mathrm{L}^{*}$ & 31.00 & \multirow{3}{*}{$\begin{array}{l}\text { main : } \mathrm{Ca}, \mathrm{S}, \mathrm{Ti} \\
\text { trace : } \mathrm{Fe}, \mathrm{Si}, \mathrm{Al}\end{array}$} \\
\hline & & $a^{*}$ & 36.67 & \\
\hline & & $b^{*}$ & -62.69 & \\
\hline \multirow{3}{*}{ Brown } & \multirow{3}{*}{ A } & $\mathrm{L}^{*}$ & 38.30 & \multirow{3}{*}{$\begin{array}{l}\operatorname{main}: \mathrm{Fe} \\
\text { trace }: \mathrm{Ca}, \mathrm{Ti}\end{array}$} \\
\hline & & $\mathrm{a}^{*}$ & 28.32 & \\
\hline & & $b^{*}$ & 28.98 & \\
\hline
\end{tabular}




\begin{tabular}{|c|c|c|c|}
\hline \multirow{3}{*}{ B } & $\mathrm{L}^{*}$ & 34.75 & \multirow{3}{*}{$\begin{array}{l}\text { main : Fe } \\
\text { trace : } \mathrm{Ca}, \mathrm{Ti}\end{array}$} \\
\hline & $a^{*}$ & 17.07 & \\
\hline & $b^{*}$ & 16.55 & \\
\hline \multirow{3}{*}{ C } & $\mathrm{L}^{*}$ & 39.39 & \multirow{3}{*}{$\begin{array}{l}\operatorname{main}: \mathrm{Fe}, \mathrm{Ca} \\
\text { trace : } \mathrm{Ti}\end{array}$} \\
\hline & $a^{*}$ & 24.96 & \\
\hline & $b^{*}$ & 24.58 & \\
\hline \multirow{3}{*}{ D } & $\mathrm{L}^{*}$ & 50.23 & \multirow{3}{*}{$\begin{array}{l}\text { main }: \mathrm{Ca}, \mathrm{Fe} \\
\text { trace : } \mathrm{Ti}\end{array}$} \\
\hline & $a^{*}$ & 23.56 & \\
\hline & $b^{*}$ & 20.02 & \\
\hline
\end{tabular}

\section{2. 내구성 평가}

제조사별 물감의 내구성을 확인하기 위해 열화 후 시 료를 대상으로 육안 및 현미경을 이용해 표면관찰을 하였 으며 광택도, 색차 측정을 실시하였다.

표면관찰 결과 모든 시료는 열화 후 육안으로도 식별 이 가능할 정도로 색이 변화했다(Table 6). 육안관찰에서 가장 눈에 띄는 변화는 C사의 Viridian에서 관찰되었는데, 자외선에 노출된 시료는 광택이 줄어든 반면 흡습-건조 에 노출된 시료의 경우 광택이 증가했다.

현미경 관찰을 통해서는 일부 시료의 표면에서 균열을 관찰할 수 있었는데, 균열은 물감 제조사별, 색상별로 손 상 발생 양상에 조금씩 차이가 있었다(Table 5). 황색의 Lemon yellow에서 가장 많은 균열이 관찰되었으며, 복원 용 물감인 $\mathrm{B}$ 사의 것에서 가장 많은 균열이 발생했다. 이 는 물감 제조 시 사용된 유향수지의 영향인 것으로 추정 된다.

광택도 측정 결과 대부분의 시료에서는 변화가 없었지 만 일부 시료에서 열화 후 광택 변화가 관찰되었다. 가장 큰 변화는 C사의 Viridian에서 관찰되었으며 자외선에 노 출된 시료에서는 광택이 감소했고, 흡습-건조 조건에서 실험한 시료에서는 광택이 증가하였다. 자외선에 노출된 Carmine에서 열화 후 광택의 감소가 관찰되었으며, 복원 용 물감인 B사의 Burnt sienna에서 열화 후 광택이 감소하 였다.

색차 측정 결과 열화 후 모든 시료에서 매우 많은 변색 이 발생했음을 확인할 수 있었다(Figure 3, 4). 가장 적은 변화는 흡습 - 건조 조건에서 실험한 $\mathrm{C}$ 사의 Viridian에서 나타났으며, 가장 큰 변화는 $\triangle E^{*} 36.52$ 로 마찬가지로 흡
습·건조 조건에서 실험한 A사의 Ultramarine blue에서 관 찰되었다(Table 6). 그 외 대부분의 시편에서도 색차값 평 가 결과 $\triangle E^{*} 12.0$ 이상의 'Very Much'에 해당하는 매우 큰 변색이 발생하였다. 열화 후 C사의 Lemon yellow, Viridian, D사의 Ultramarine blue을 제외한 모든 시료에서 명도가 감소하는 경향이 뚜렷하게 관찰되었으며, 색상별 로 변색 정도는 차이를 보였다.

색상별로 살펴보면, 가장 적은 변화가 나타난 것은 갈 색의 Burnt sienna였으며 녹색(Viridian), 적색(Carmine), 황 색(Lemon yellow), 청색(Ultramarine blue)순으로 색도 변 화가 나타났다. Carmine의 경우 열화 조건에 상관없이 모 든 시료에서 열화 후 모든 시료에서 $\mathrm{L}^{*}, \mathrm{a}^{*}, \mathrm{~b}^{*}$ 값이 감소 하는 경향을 보였다. Lemon yellow는 열화 후 $\mathrm{b}^{*}$ 값이 크 게 감소하였으며 명도가 줄고 적색도와 청색도가 높아지 는 경향을 보였다. 다만 C사의 Lemon yellow는 다른 제조 사의 물감과 달리 열화 후 명도가 증가했으며, 적색도를 뜻하는 a* 값의 경우 자외선에 노출한 결과 증가했지만, 흡습·건조 조건에 노출한 결과 감소하였다. Viridian은 자외선에 노출된 아크릴과슈 시료에서 황색도를 뜻하는 $b^{*}$ 값이 감소한 것을 제외하고는 두 조건 모두에서 $\mathrm{L}^{*}$ 값 이 감소하고, $a^{*}, b^{*}$ 가 증가하는 경향을 보였다. 발색특성 비교에서 가장 색이 달랐던 $\mathrm{C}$ 사 Viridian의 경우 적색도를 뜻하는 $\mathrm{a}^{*}$ 값이 감소하였음을 확인할 수 있었다. Ultramarine blue는 자외선 실험을 한 $\mathrm{D}$ 사의 $\mathrm{L}^{*}$ 값이 증가 한 것을 제외하고는 $\mathrm{L}^{*}, \mathrm{a}^{*}, \mathrm{~b}^{*}$ 값이 모두 감소하는 경향 을 보였으며, Burnt sienna는 모든 시료에서 $L^{*}, a^{*}, b^{*}$ 값 이 감소하였다. 
Table 5. Experimental results by microscopic observation $(\times 100)$

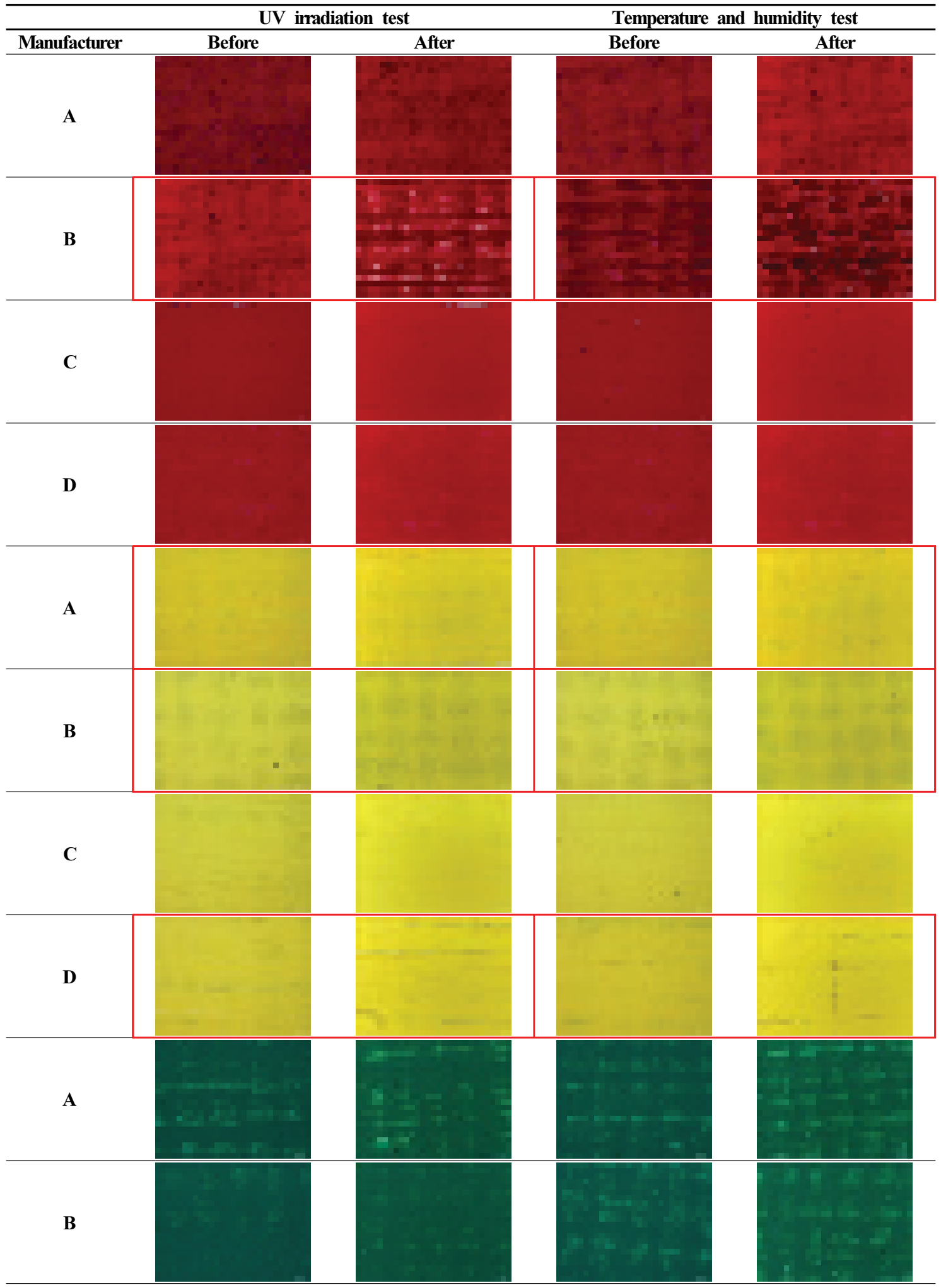


유화 작품 색맞춤용 재료 특성 연구 / 최희진, 강대일 | 435

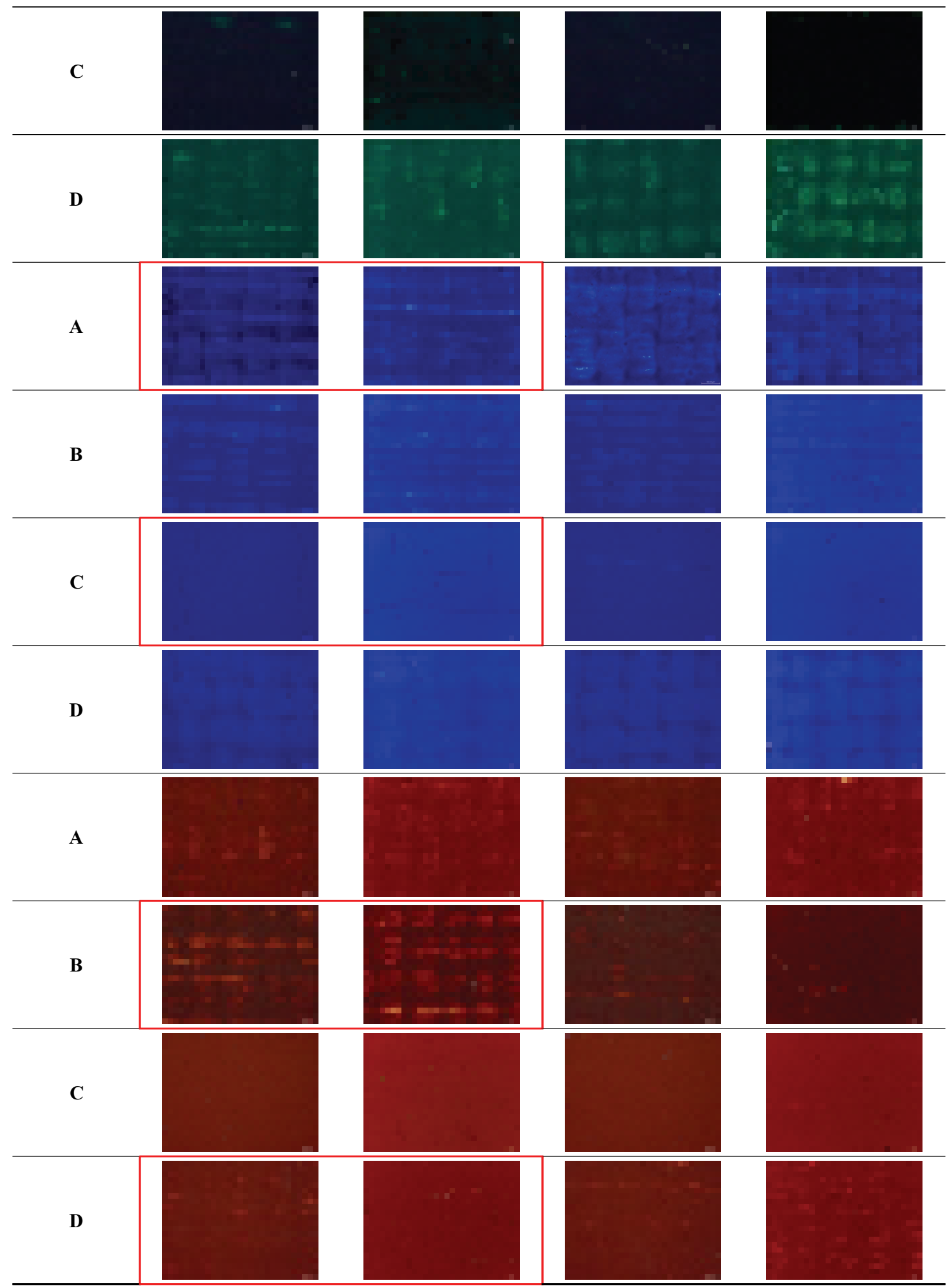


Table 6. The results by visual observation and Chroma values of samples after test

\begin{tabular}{|c|c|c|c|c|c|c|c|c|c|}
\hline & & \multicolumn{4}{|c|}{ UV imadiation test } & \multicolumn{4}{|c|}{ Accelerated aging test } \\
\hline & & $\mathbf{A}$ & B & $\mathbf{C}$ & D & $\mathbf{A}$ & B & C & D \\
\hline \multirow{4}{*}{ Red } & Before & & & & & & & & \\
\hline & After & & & & & & & & \\
\hline & $\Delta E$ & 13.69 & 11.62 & 17.33 & 15.79 & 12.84 & 12.39 & 17.46 & 15.20 \\
\hline & $\Delta G$ & -0.8 & -0.1 & -0.1 & -0.1 & -0.2 & - & - & - \\
\hline \multirow{4}{*}{ Yellow } & Before & & & & & & & & \\
\hline & After & & & & & & & & \\
\hline & $\Delta E$ & 34.64 & 23.56 & 23.59 & 29.95 & 35.57 & 24.41 & 21.05 & 30.68 \\
\hline & $\triangle G$ & - & - & - & - & - & - & - & - \\
\hline \multirow{4}{*}{ Green } & Before & & & & & & & & \\
\hline & After & & & & & & & & \\
\hline & $\Delta E$ & 15.48 & 13.03 & 13.26 & 10.82 & 14.28 & 12.22 & 2.64 & 11.23 \\
\hline & $\triangle G$ & - & - & -0.2 & - & - & - & 4.8 & - \\
\hline \multirow{4}{*}{ Blue } & Before & & & & & & & & \\
\hline & After & & & & & & & & \\
\hline & $\triangle E$ & 32.40 & 23.06 & 23.51 & 23.02 & 36.52 & 25.94 & 25.48 & 36.08 \\
\hline & $\Delta G$ & - & - & - & - & - & - & - & - \\
\hline \multirow{4}{*}{ Brown } & Before & & & & & & & & \\
\hline & After & & & & & & & & \\
\hline & $\triangle E$ & 15.86 & 11.10 & 10.38 & 7.86 & 17.76 & 10.27 & 9.25 & 11.11 \\
\hline & $\Delta G$ & - & -1.7 & - & - & - & -0.5 & - & - \\
\hline
\end{tabular}




\section{UV irradiation test results}
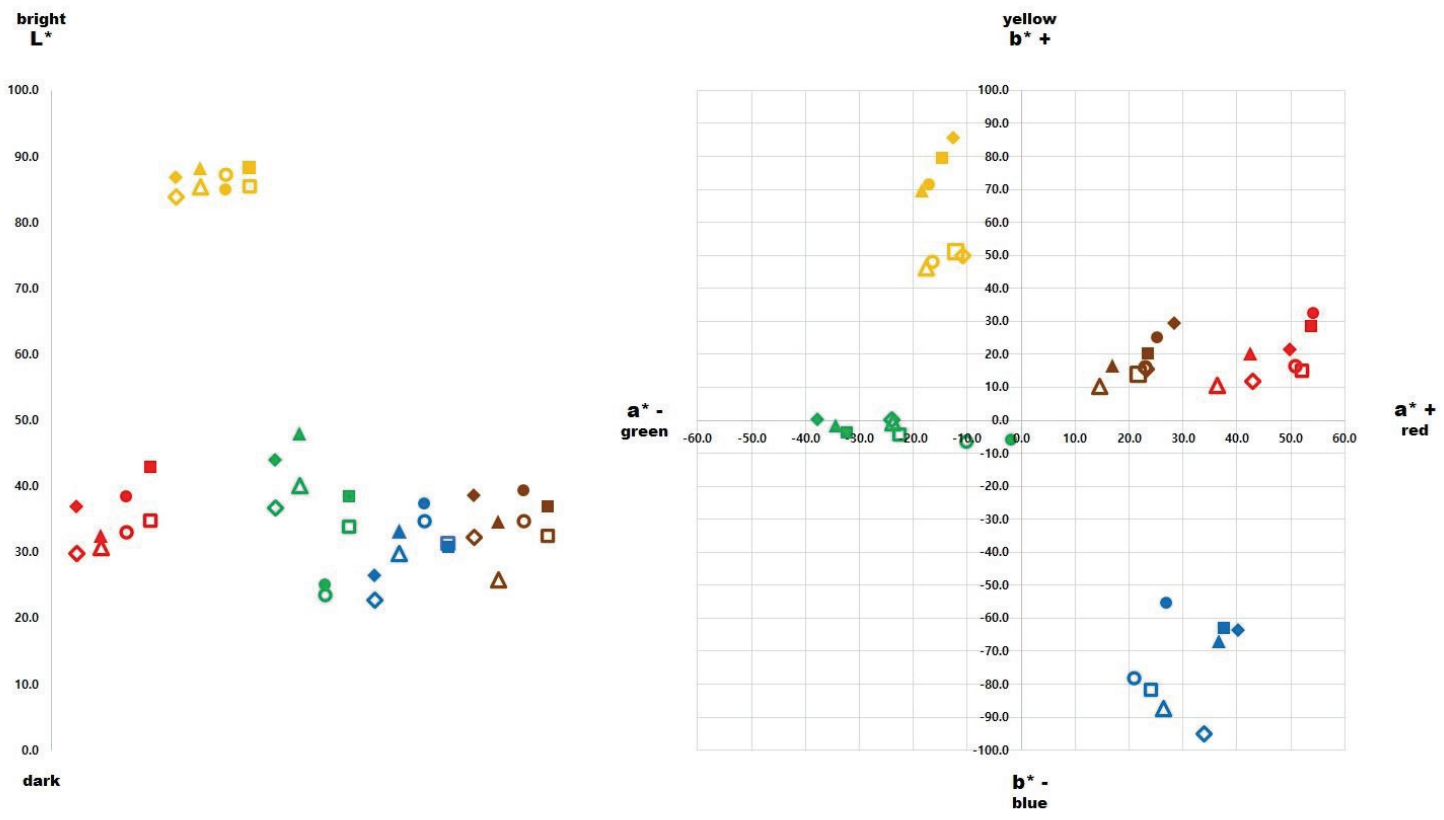

$\diamond_{A}$ unaged $\diamond_{A}$ aged $\quad \Delta$ B unaged $\Delta B$ aged $\quad C_{\text {unaged }} O^{C}$ aged $\quad \square$ unaged $\square$ aged

Figure 3. CIE $\mathrm{L}^{*} \mathrm{a}^{*} \mathrm{~b}^{*}$ diagram of the samples before and after UV irradiation test showing the shifts of their $\mathrm{L}^{*}, \mathrm{a}^{*}$ and $b^{*}$ coordinates.

\section{Temperature and Humidity test results}
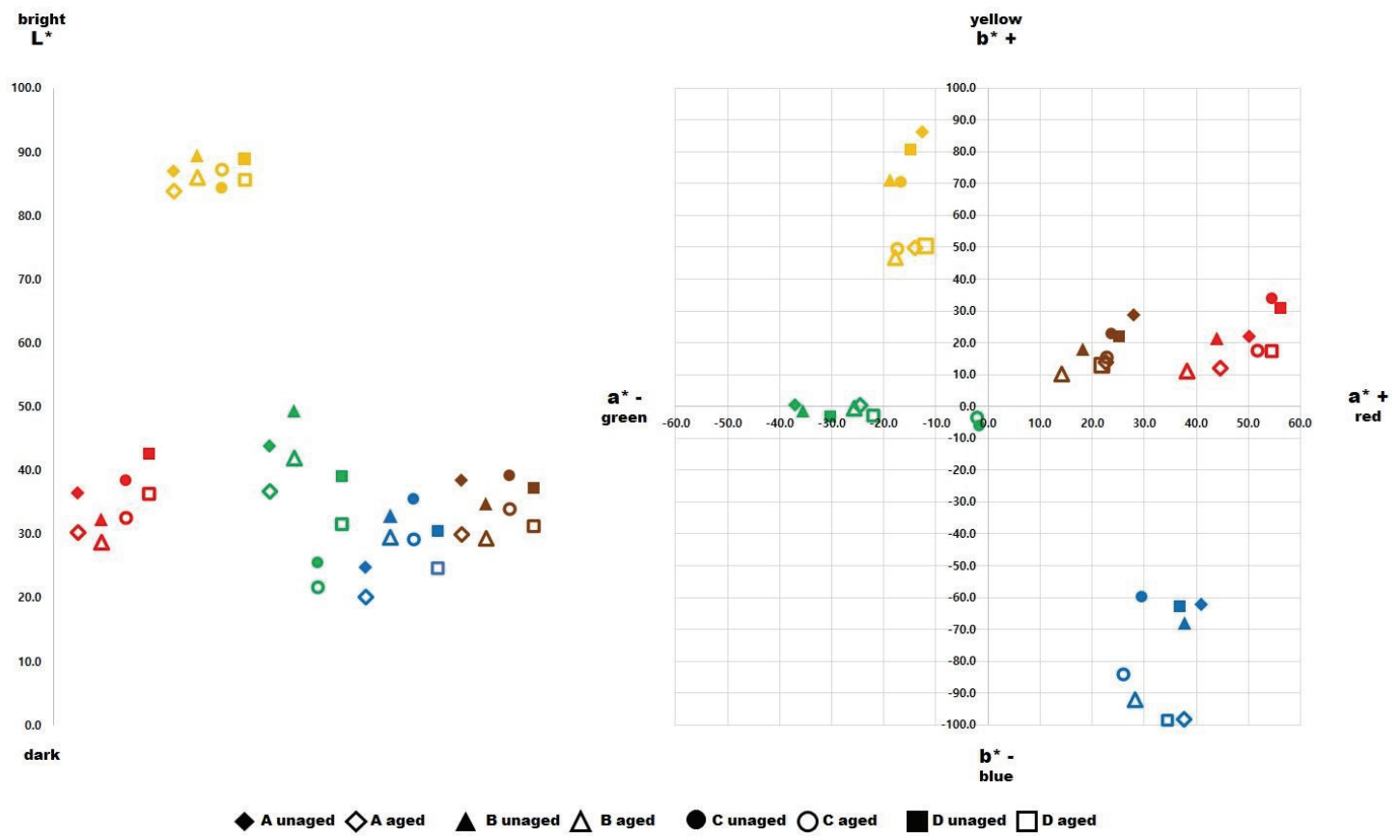

Figure 4. CIE L*a*b* diagram of the samples before and after Temperature and Humidity test showing the shifts of their $\mathrm{L}^{*}, \mathrm{a}^{*}$ and $\mathrm{b}^{*}$ coordinates. 


\section{5. 결 론}

본 연구에서는 복원용 물감 2종, 아크릴과슈 2종 총 4 개 제조사에서 색명이 동일한 물감을 5종씩 선정한 후 성 분 분석 및 열화 실험을 하였다. 그 결과 색에 따라 제조 사에 따라 발색 특성 및 성분 차이, 변색, 균열과 같은 열 화 특성의 차이가 존재했다.

녹색의 Viridian은 변색과 균열 모두에서 비교적 안정 한 편이었다. 하지만 실험에서 황색 물감으로 선정한 Lemon yellow의 경우 실험 결과 복원용 물감인 A사와 B 사, 아크릴과슈인 $\mathrm{D}$ 사의 것에서 균열이 관찰되었으며 변 색 역시 많이 발생하였다. 따라서 색맞춤을 위해 이를 사 용할 경우 향후 전시과정에서 빛에 노출됨에 따라 단기간 에 변색, 균열이 발생할 수 있고 복원부 이질감뿐만 아니 라 작품의 보존성에도 영향을 줄 수 있다는 것을 인지하 고 사용해야 할 것이다.

$\mathrm{A}$ 사의 물감들은 균열에 있어 비교적 안정한 편이었으 나, 적색의 Carmine을 제외하고 다른 색상에서 가장 많은 변색이 관찰되었다. 색맞춤에 사용되는 재료인 만큼 이를 고려하여야 할 것이다. $\mathrm{B}$ 사의 물감들은 변색에 있어 가장 안정한 편이었으나, 균열이 가장 많이 발생하였다. 일부 시료에서는 광택의 감소도 관찰되었으며, 이는 물감 제조 시 사용된 유향수지의 영향으로 건조 과정에서의 빠른 증 발에 따른 것으로 보인다(De La Rie, 2000). C사는 균열과 변색 모두에서 비교적 안정한 편이었으나, 발색특성에 있 어 다른 제조사와 큰 차이를 보였다. 또한 C사의 Viridian 은 발색에서도 큰 차이를 보였지만, 온습도 조건에 노출 된 후 광택이 크게 증가하였으므로 사용 시 광택 변화를 주의해야 할 것이다. 광택 증가의 경우 온습도에 노출됨 에 따라 물감 제조 시 전색제로 사용된 수지의 변형에 따 른 것으로 보이며(SchuĖtz, 1999) 보다 정확한 원인 규명 을 위해 향후 추가적인 연구가 필요할 것으로 보인다. $\mathrm{D}$ 사는 균열과 변색 모두 많이 발생한 편이었기에 사용 시 주의해야 할 것이다.

연구 결과 유화 작품의 색맞춤을 위해 개발된 복원용 물감에서도 열화 후 변색, 균열 등 물리적 특성 변화가 관찰되었다. 이는 제조 시 사용된 수지 및 제조 기법에 따른 것으로 보인다. 유화 작품의 색맞춤을 위해 개발된 재료인 만큼 보존처리자들은 복원용 물감을 사용해 색맞 춤 할 경우 오랜 기간 안정적으로 물성을 유지할 것으로 기대하고 사용하지만 본 연구를 통해 복원용 물감도 다양 한 환경 인자에 의해 물리, 화학적 변화가 발생하며 균열, 변색이 발생한다는 것이 확인되었다. 현재 다양한 제조사 에서 각기 다른 합성수지를 이용해 제작한 복원용 물감이
시판되고 있으나 합성수지의 차이에 따른 물감의 특성 및 내구성과 가역성, 열화 패턴 연구는 미흡한 실정이다. 보 존처리에 있어 사용하는 재료의 안정성과 가역성을 전제 조건으로 하는 현대 보존 이론에 입각해 보았을 때 유화 색맞춤에 사용되는 복원용 물감의 특성을 연구하고 열화 에 손상을 미치는 환경 인자, 가역성 등을 파악하는 것은 필수적일 것이다. 특히 실제 작품이나 복원부에서 발생하 는 균열, 변색 등의 물리적 특성 변화는 복합적인 원인에 의해 발생하므로 이에 대해서는 정확한 원인 규명 및 특 성 확인을 위해 변수를 통제하고 다양한 분석법을 이용해 추가적인 연구를 진행할 예정이다.

유화 색맞춤에 사용되고 있는 재료들은 실제 회화작품 의 보존처리에 사용되는 재료인 만큼 실제 적용에 앞서 재료의 특성, 보존처리용 재료로서의 적합성 등이 검증되 어야 한다. 그러나 이에 관한 연구는 부족하고 추가적인 실험을 통한 안정성 검증 없이 처리에 적용되고 있는 현 실이다. 복원용으로 개발된 물감에서도 상당한 물리적 특 성 변화가 관찰된 만큼 처리자는 이를 고려하여 재료의 사용에 앞서 이들의 특성, 열화 패턴을 확인하고 향후 나 타날 수 있는 문제점을 파악한 후 사용하여야 할 것이다. 또한 처리에 사용되는 재료는 어떤 경우에도 작업의 용이 성, 편리성보다는 안정성과 가역성을 첫 번째 전제조건으 로 하여야 한다는 것을 명심하고 재료 선정 시 이를 고려 해야 할 것이다.

본 연구에서는 5 색을 대상으로 실험을 진행하였으나, 추후 다양한 색상과 열화 조건으로 실험을 진행한다면 보 다 유의미한 결론을 얻을 수 있을 것으로 보인다. 본 연구 결과는 유화 작품 보존처리 시 고려해야 할 색맞춤용 재 료의 안정성에 관한 정보를 제공하였으며, 향후 유화 작 품 보존처리 시 색맞춤을 위한 재료 선정 및 보존처리에 참고자료로 활용될 수 있길 기대하는 바이다.

\section{REFERENCES}

Chelazzi, D., Chevalier, A., Pizzorusso, G., Giorgi, R., Menu, M. and Baglioni, P., 2014, Characterization and degradation of poly(vinyl acetate)-based adhesives for canvas paintings, Polymer Degradation and Stability, 107, 314-320.

De La Rie, E.R., Quillen Lomax. S., Palmer. M., Deming Glinsman. L. and Christopher A. Maines., 2000, An investigation of the photochemical stability of urea-aldehyde resin retouching paints: removability tests and colour spectroscopy, Studies in Conservation, 45:1, 51-59.

Geiger. T. and Michel. F., 2005, Studies on the Polysaccharide 
JunFunori used to consolidate matt paint, Studies in Conservation, 50(3), 193-204.

Gettens, R.J. and Stout, G.L., 1996, Painting materials: A short encyclopaedia, Dover Publications, New York.

Kim, J.E., 2008, A study of colors by accelerating test, Kyunggi University, Suwon. (in Korean with English abstract)

Kim, J.H., Park, H.S. and Lim, S.J., 2017, Comparison study on the material characteristics of oil paints ( I ). Journal of Conservation Science, 33(2), 85-95. (in Korean with English abstract)

Kogou, S., Lee. L., Shahtahmassebi. G. and Liang, H., 2021, A new approach to the interpretation of XRF spectral imaging data using neural networks, X-Ray Spectrometry, 50(4), 310-319.

Lee, H.H., 2009, A study on the color properties of a pigment oil color changes and light resistance experiments.
Master's thesis, Hongik University, Seoul. (in Korean with English abstract)

Nicolaus. K., 1999, The restoration of painting, Konemann, Cologne.

SchuÈtz, E., F. Berger., O. Dirckx. and A. Chambaudet, 1999, Study of degradation mechanisms of a paint coating during an artificial aging test, Polymer Degradation and Stability, 65, 123-130.

Seo, J.H., 2004, Study on the pigment in the material of oil paint, Master's thesis, Kyonggi University, Suwon. (in Korean with English abstract)

Wolbers, R.C., McGinn. M. and Duerbeck, D., 1994, Poly(2-Ethyl-2-Oxazoline): A new conservation consolidant, in Proceedings of Painted Wood: History and Conservation, Dorge V., Howlett F.C.(Ed.), Getty Conservation Institute, Los Angeles. 